\title{
Sistemska ureditev urjenja kompetenc v okviru supervizirane prakse
}

\author{
Anja Podlesek \\ Univerza $v$ Ljubljani \\ anja.podlesek@ff.uni-lj.si
}

\begin{abstract}
V kariernem razvoju psihologov je za zagotavljanje ustreznih kompetenc izjemnega pomena supervizirana praksa, zato naj bi se vsak psiholog začetnik v prvem letu zaposlitve vključil v supervizijo pri usposobljenem mentorju. V prispevku je opisan program Super psiholog, ki podpira izvajanje supervizirane prakse psihologov začetnikov. Razvit je bil v letih 2015-2016 v projektu "Supervizirana praksa psihologov: razvoj programa usposabljanja mentorjev in modela supervizirane prakse - Super psiholog «, ki je potekal v okviru programa Norveškega finančnega mehanizma. Opisani so potek mentoriranja, vsebina mentorskih srečanj in različne vloge mentorja supervizirane prakse. Predstavljen je pomen posebnega usposabljanja za mentorja supervizirane prakse in program usposabljanja, kot je bil razvit v projektu Super psiholog. Za pomoč pri izvajanju supervizirane prakse so bile v projektu razvite Smernice za izvajanje supervizirane prakse psihologov. Na kratko so predstavljena tudi spoznanja iz projekta, ki podpirajo primerjalno prednost mentoriranja po programu Super psiholog pred klasičnim pripravništvom.
\end{abstract}

\section{Pomen supervizirane prakse za zagotavljanje kompetenc psihologov}

Med petletnim akademskim študijem psihologije posameznik še ne more razviti vseh kompetenc, ki so potrebne za izvajanje psiholoških storitev. Šele na delovnem mestu, ko se sreča $\mathrm{z}$ realnimi problemi, s klienti in $\mathrm{z}$ etičnimi dilemami, začne integrirati teoretično znanje in praktične veščine, razvije svojo poklicno vlogo, se usposobi za delo s specifičnimi skupinami klientov, usvoji zakonodajo, ki ureja področje dela, razvije zavedanje samega sebe, refleksivnost, osebno integriteto in etično kompetentnost. Pri delu z ljudmi, posebej tistimi s težavami ali v stiski, lahko prihaja do zahtevnih in stresnih situacij, s katerimi se mora biti zmožen ustrezno sproprijemati. Pri tem ne sme biti prepuščen samemu sebi. Zaradi odgovornosti do klientov, družbe, stroke in sebe se mora psiholog začetnik vključiti v supervizijo, ki mu pomaga razviti vse tiste kompetence, ki jih potrebuje za kakovostno opravljanje psihološke dejavnosti. 


\section{Mentorski program Super psiholog}

Mentorski program Super psiholog predstavlja enoletno supervizirano prakso na začetku opravljanja poklica psihologa (supervizirano prakso $p s i-$ hologov). Ime programa izhaja iz istoimenskega projekta, ki je v letih 2015 in 2016 potekal v okviru programa Norveškega finančnega mehanizma 2009-2014 (Supervizirana praksa psihologov: razvoj programa usposabljanja mentorjev in modela supervizirane prakse - Super psiholog). Cilj projekta je bil razviti sistem supervizirane prakse psihologov v Sloveniji, poskrbeti, da bi imeli vsi psihologi možnost vključitve v supervizijo na začetku poklicne poti, ter ustvariti pogoje za visokokakovostno supervizijo in s tem maksimalno zaščito klientov. Tako bi omogočili tudi doseganje standardov za samostojno opravljanje psihološke dejavnosti in pridobitev evropskega certifikata iz psihologije - EuroPsy.

V programu Super psiholog se psiholog začetnik poveže z mentorjem supervizirane prakse (oz. supervizorjem), ki obvlada strokovno področje začetnikovega dela in mu tako lahko nudi podporo pri razvijanju potrebnih kompetenc za delo. Mentorski par sklene mentorski sporazum, v katerem natančno opredeli cilje mentoriranja, način sodelovanja, dolžnosti in pravice obeh v paru. Supervizija poteka dve uri na vsaka dva tedna v za to posebej rezerviranem času. Začetnik mentorju predstavi svoje delo, bodisi skozi verbalne opise pomembnih primerov bodisi tako, da mentor opazuje začetnika pri delu, najpogosteje skozi uporabo zvočnih ali videoposnetkov tega dela. Par natančno analizira začetnikovo delo, o njem razpravlja in kritično reflektira opaženo. Začetnik tako lahko predeluje svoje delo na miselni in čustveni ravni. Supervizija poleg opazovanja vključuje tudi mentorjevo dajanje navodil, prikaz postopkov, skupno reševanje problemov, refleksijo, evalvacijo in podajanje povratnih informacij. Skozi mentorjevo reflektiranje in vrednotenje začetnikovega dela začetnik postopno razvije zavedanje ravni razvitosti svojih kompetenc in realno samooceno (European Federation of Psychologists' Associations, 2015).

Mentor psihologu začetniku pomaga pri integraciji teoretičnih in praktičnih znanj, ga usmerja pri delu, z njim razpravlja o različnih možnostih, uporabi optimalnih postopkov. Mentoriranje ima torej edukativno funkcijo. Poleg tega mentor s sodelovalnim odnosom podpira začetnika pri razvoju njegovih strokovnih kompetenc. Omogoči mu varno okolje za učenje, raziskovanje lastnih odzivov na delovne situacije, preizkušanje različnih rešitev. Pomaga mu, da se sooča in zmanjšuje dvome vase, anksioznost, da deli in predela neprijetna doživetja, povezana $\mathrm{z}$ delom, kar je pomembno 
pri ohranjanju začetnikovega ravnovesja, čvrstosti in duševnega zdravja, ter pri preprečevanju izgorevanja (Žvelc, 2016). Poleg tega pa ima mentor tudi nadzorno funkcijo. Ob zaključku supervizirane prakse oceni začetnikove kompetence in presodi, ali je usposobljen za to, da začne samostojno opravljati psihološko dejavnost. S tem je mentor "vratar sistema" in njegova odločitev zagotavlja, da psihološko dejavnost opravljajo samo ustrezno usposobljeni posamezniki, tj. tisti, ki imajo vsa potrebna znanja in veščine ter tudi primerno naravnanost do opravljanja psihološke dejavnosti.

Da lahko mentor kakovostno opravlja vse navedene funkcije, mora zaključiti posebno usposabljanje za mentorja supervizirane prakse. V projektu Super psiholog smo razvili dveletni (160-urni) program, ki pri mentorjih razvija kompetence mentoriranja in supervizije. Mentorji v programu spoznajo, katere kompetence morajo razvijati pri psihologu začetniku in kako poteka razvoj mentorskega odnosa. Naučijo se načrtovati, dokumentirati in evalvirati supervizirano prakso. Spoznajo metode in potek supervizije, razvijejo veščine supervizije in se naučijo vzpostaviti ustrezen supervizijski odnos. Spoznajo tudi pomen prepoznavanja in preprečevanja težav v začetnikovem duševnem zdravju ter skrbi zase. Mentorji se $\mathrm{v}$ okviru usposabljanja preizkusijo $\mathrm{v}$ vodenju supervizirane prakse psihologa začetnika in tako razvijajo kompetence aktivnega poslušanja, reflektiranja, dajanja povratnih informacij, obvladovanja meja v mentorskem odnosu ter razmerij moči, reševanja konfliktov in etičnih dilem itd. Vključeni so v supervizijsko skupino, sestavljeno iz več mentorjev in supervizorja. $V$ skupini razpravljajo o svojem mentoriranju, ga reflektirajo in evalvirajo. Supervizija mentorja je namenjena kakovostnemu mentoriranju in v usposabljanju mentorjev igra posebno vlogo.

Delo mentorskega para v času supervizirane prakse je podprto na različne načine. Paru so na spletišču www.superpsiholog.si na voljo informacije o supervizirani praksi, njenem pomenu in načinu njenega izvajanja. Dostopna so natančna navodila, kako izvajati mentorska srečanja. Na voljo so smernice za izvajanje supervizirane prakse, ki so bile razvite v okviru projekta Super psiholog in kjer mentorji najdejo vodila, s katerimi si lahko pomagajo pri svojem mentoriranju oz. superviziji. Mentorski par lahko pri delu uporablja različne pripomočke za vzpostavljanje mentorskega odnosa in njegov razvoj, za načrtovanje supervizirane prakse, refleksijo o njej in evalvacijo ter za ocenjevanje kompetenc začetnika. Na spletni platformi mentorski par dokumentira potek mentorskih srečanj. Društvo psihologov Slovenije kot skrbnik sistema supervizirane prakse povezuje začetnike 
in mentorje, spremlja izvajanje supervizirane prakse, skrbi za njen ustrezen potek in ponuja pomoč mentorskim parom, kadar jo potrebujejo. Prav tako skrbi za finančne vidike vodenja sistema supervizirane prakse, organizacijo usposabljanj psihologov začetnikov, mentorjev supervizirane prakse in supervizorjev mentorjev ter za promocijo supervizirane prakse na univerzah, pri psihologih, njihovih delodajalcih in v širši javnosti.

\section{Smernice za izvajanje supervizirane prakse psihologov}

Z zbranimi izkušnjami in s sodelovanjem udeležencev v projektu Super psiholog smo pripravili smernice za izvajanje supervizirane prakse (Podlesek, Pelc idr., 2016). Smernice so namenjene vsem udeleženim v sistemu supervizirane prakse: psihologom začetnikom, mentorjem, supervizorjem mentorjev, izvajalcem usposabljanj in skrbnikom sistema supervizirane prakse. Določajo minimalen obseg mentorskih srečanj, način vzpostavljanja mentorskih parov, strukturo in vsebine mentorskih srečanj (spoznavanje in izmenjava pričakovanj, sklepanje mentorskega sporazuma, komunikacija s klienti, etične dileme, kompetence mentoriranca, zakonito delovanje mentoriranca, refleksija, podajanje povratnih informacij, mentorski odnos, evalvacija mentoriranja, zaključevanje mentorskega odnosa), oblike mentorskih srečanj, časovna in prostorska priporočila za izvajanje teh srečanj, pripravo gradiv za srečanja ter dokumentiranje srečanj. V smernicah so zapisana tudi vodila za izvedbo supervizije mentoriranja. Predstavljen je predlog načinov pripravljanja študentov in psihologov začetnikov na supervizirano prakso ter potek usposabljanja mentorjev in supervizorjev mentorjev. Smernice obravnavajo še druge vidike sistema supervizirane prakse, npr. spletno platformo za dokumentiranje poteka supervizirane prakse, financiranje sistema supervizirane prakse in promocijo supervizirane prakse.

\section{Spoznanja iz projekta Super psiholog}

Supervizirana praksa je bila v projektu Super psiholog med mentorji in psihologi začetniki sprejeta zelo dobro. $\mathrm{V}$ primerjavi z izkušnjami, ki so jih imeli z mentoriranjem pred projektom, so supervizirano prakso prepoznali kot bolj strukturiran in sistematičen proces. Sklenitev mentorskega sporazuma je spodbudila dosledno delovanje mentorskega para, redno refleksijo mentorskih srečanj in evalvacijo doseženega (Kocbek idr., 2016). Psihologi začetniki so menili, da so $\mathrm{v}$ tem mentorskem programu pridobili več kot pri drugih načinih mentoriranja in so se ob zaključku supervizirane prakse počutili bolj pripravljene za samostojno delo (Poredoš, 2016; Podle- 
sek, Bučar idr., 2016). Vključenost v mentorski program pa ni spodbujala razvoja kompetenc le pri psihologih začetnikih, temveč tudi pri mentorjih. Mentorji niso razvili le kompetenc na področju mentoriranja, temveč so napredek zaznali tudi v svojem profesionalnem razvoju in pri svojem strokovnem delu, prav tako pa so poročali o poglobitvi poklicne identitete (Kocbek idr., 2016; Pirc idr., 2016; Štirn idr., 2016). Oboji so supervizijo prepoznali kot pomemben del delovanja psihologa, ne le na začetku, temveč skozi celotno kariero.

\section{Opombe}

Del besedila prispevka je bil predstavljen na Prvi slovenski mentorski konferenci, Ljubljana, 10. februar 2017.

\section{Literatura}

European Federation of Psychologists' Associations. (2015). EuroPsy: European certificate in psychology; E F PA regulations on EuroPsy and appendices.

Kocbek, K., Ponikvar, K., in Podlesek, A. (2016). Evalvacija supervizirane prakse 1: Poročila mentorjev in mentorirancev ter ocene njihovih kompetenc. VA. Podlesek (ur.), Razvoj sistema supervizirane prakse psihologov $v$ Sloveniji (str. 237-254). Znanstvena založba Filozofske fakultete.

Pirc, T., Podlesek, A., Poštuvan, V., Podlogar, T., Kocbek, K., in Ulčar, M. (2016). Evalvacija programa usposabljanja mentorjev supervizirane prakse. V A. Podlesek (ur.), Razvoj sistema supervizirane prakse psihologov v Sloveniji (str. 205-216). Znanstvena založba Filozofske fakultete.

Podlesek, A., Bučar, S., Skrbinšek, T., in Kocbek, K. (2016). Evalvacija supervizirane prakse 2: primerjava učinkovitosti supervizirane prakse $\mathrm{z}$ drugimi oblikami usposabljanja psihologov začetnikov. V A. Podlesek (ur.), Razvoj sistema supervizirane prakse psihologov v Sloveniji (str. 255-273). Znanstvena založba Filozofske fakultete.

Podlesek, A., Pelc, J., Kocbek, K., Zabukovec, V., Štirn, M., Poštuvan, V., Pirc, T., Straumsheim, P. A., Duckert, M., Kyte, B., Bučar, S., in Ponikvar, K. (2016). Smernice za izvajanje supervizirane prakse psihologov. Znanstvena založba Filozofske fakultete.

Poredoš, M. (2016). Primer izkušnje s študijsko prakso v projektu Super psiholog. V A. Podlesek (ur.), Razvoj sistema supervizirane prakse psihologov $v$ Sloveniji (str. 179-183). Znanstvena založba Filozofske fakultete.

Štirn, M., Tacer, B., Rihter, A., Kovačik, A., Pelc, J., Poštuvan, V., in Čepon, S. (2016). Evalvacija supervizije mentorjev supervizirane prakse psihologov. V A. Podlesek (ur.), Razvoj sistema supervizirane prakse psihologov $v$ Sloveniji (str. 275-280). Znanstvena založba Filozofske fakultete.

Žvelc, M. (2016). Supervizija: opredelitev, funkcije in modeli supervizije ter supervizijska aliansa. V A. Podlesek (ur.), Razvoj sistema supervizirane 
prakse psihologov v Sloveniji (str. 31-50). Znanstvena založba Filozofske fakultete.

\section{Systematic Regulation of Competency Training within Supervised Practice}

In the career development of psychologists, supervised practice is of paramount importance for the provision of appropriate competencies. In the first year of work, each novice psychologist is expected to enter supervision with a qualified supervisor. The paper describes the Super Psiholog programme, which supports the implementation of supervised practice of novice psychologists. The programme was developed in the years 2015-2016 in the project 'Supervised Practice of Psychologists: Development of a Training Programme for Mentors and a Model of Supervised Practice (Super Psiholog),' which was carried out within the Norway Grants programme. The course of supervision, the content of supervision meetings, and the different roles of supervisors are described. The importance of special training for the supervisors and the training program as developed in the Super Psiholog project are presented. To assist in the implementation of supervised practice, Guidelines for the Supervised Practice of Psychologists were developed in the project. The experiences gained in the project, which support the comparative advantage of supervision following the Super Psiholog program over classic probation internships, are also briefly presented. 